UNIVERSITY OF GOTHENBURG

SCHOOL OF BUSINESS, ECONOMICS AND LAW

WORKING PAPERS IN ECONOMICS

No 546

Biodiversity Conservation and Ecosystem Services Provision:

Tale of Confused Objectives, Multiple Market Failures and Policy Challenges

Jessica Coria, Elizabeth Robinson, Henrik G. Smith, and Thomas Sterner

October 2012

ISSN 1403-2473 (print)

ISSN 1403-2465 (online)

Department of Economics

School of Business, Economics and Law at University of Gothenburg

Vasagatan 1, PO Box 640, SE 40530 Göteborg, Sweden

+46 31786 0000, +46 317861326 (fax)

www.handels.gu.se info@handels.gu.se 


\title{
Biodiversity Conservation and Ecosystem Services Provision: A Tale of Confused Objectives, Multiple Market Failures and Policy Challenges
}

\author{
Jessica Coria ${ }^{a}$, Elizabeth Robinson ${ }^{b}$, Henrik G. Smith ${ }^{c}$, and Thomas Sterner ${ }^{d}$
}

\begin{abstract}
Most research and funding in conservation has been oriented toward biodiversity per se. Until recently there has been little tangible effort in linking conservation to ecosystem service provision. Nevertheless, this trend seems to be changing due in part to the relative success of payment mechanisms that provide funding for the conservation of ecosystem services defined as discrete and identifiable end-products. This paper describes the features of "optimal policies" to protect (i) biodiversity vs. (ii) ecosystem services and analyze to what extend the criteria in (i) and (ii) set against each other or create synergies. We also analyze how payments for ecosystem services affect the relationship between biodiversity and ecosystem services conservation.
\end{abstract}

Keywords: Biodiversity conservation, ecosystem services, synergies and trade-offs, environmental policies.

JEL Codes: Q23, Q24, Q28, Q29.

${ }^{(a)}$ Department of Economics, University of Gothenburg, Sweden. Email:

Jessica.Coria@economics.gu.se.

${ }^{(b)}$ School of Agriculture, Policy, and Development University of Reading, UK, and Department of Economics, University of Gothenburg, Sweden. Email: e.j.robinson@ reading.ac.uk.

${ }^{(c)}$ Department of Animal Ecology, University of Lund, Sweden. Email: henrik.smith@ zooekol.lu.se

${ }^{(d)}$ Corresponding Author. Department of Economics, University of Gothenburg. Email:

Thomas.Sterner@economics.gu.se.

Financial support from the Biodiversity Ecosystems and Climate Change Program (BECC) to the Environmental Economics Unit at the University of Gothenburg, and to the Department of Animal Ecology at the University of Lund is gratefully acknowledged. 


\section{Conserving Biodiversity or Ecosystem Services?}

Human impacts on the environment are intensifying, raising seriously the fundamental questions of how to protect nature itself and how to best allocate the limited resources available for biodiversity conservation. Protecting "Nature" is however a complex task that begs the question of what nature to protect and how. We believe there has been a tendency to use the word "biodiversity" as a proxy for what we want to protect since it sounds more precise. This is however somewhat of a misunderstanding: biodiversity can be measured in a number of different ways and some measures would not give the answers we are intuitively seeking. This brings us to the question of whether we should put the emphasis on biodiversity itself or on the ecosystem services that may flow from a well-functioning ecosystem? The first approach focuses on biodiversity for its own sake, independent of human needs or preferences. The second focuses on preserving biodiversity for its role in promoting ecosystem services for the provision of goods, basic-life support services and human enjoyment of nature (Balvanera et al. 2001; Mace et al. 2012). So far there has been a relative imbalance in the attention devoted to the former as most research and funding in conservation has been oriented toward biodiversity per se, with until recently, little concrete effort towards conserving biodiversity for its role in ecosystem service production.

Conservation efforts often focus on maintaining biodiversity as measured by the number of species present at a particular place. Since threats to biodiversity are distributed unevenly, the spatial limits of biodiversity is recognized, spawning a group of terms $-\alpha, \beta$ and $\gamma$ diversity differentiating between local species richness ( $\alpha$ diversity, the number of species at a location), the regional species pool ( $\gamma$ diversity, the number of different species that could be at a location) and variability between localities ( $\beta$ diversity). In the long term, however, persistence of species requires not only maximizing their representation in places where they are currently present, but crucially also minimizing the probability of their being lost (Rodrigues et al. 2006). The International Union for the Conservation of Nature (IUCN) Red List of Threatened Species (www.iucnredlist.org) is the accepted standard for species global extinction risk. Both governmental and non-governmental organizations increasingly rely on the IUCN Red List to inform priorities, influence legislation, and guide conservation investment (Rodrigues et al. 2006). 
Concentrating on the number of species and taking threat rankings at face value to define conservation priorities reduces biodiversity to a simple metric which is easy to comprehend; however when it comes to the link between biodiversity and ecosystem functioning, much evidence points to a strong role for species identity (Bengtsson 1998; Diaz et al. 2005). That is, the composition of ecological communities and even the presence of individual dominant species (e.g., keystone species or ecosystem engineers) can play a key role in controlling ecosystem function, rather than the number of species per se (Chapin et al. 2000).

What is the implication for policy making? In policy there has been considerable emphasis on the need to protect biodiversity universally due to the potential benefits that this may have for ecosystem function. The fact that biodiversity may be positively associated with the ability of systems to deal with changing environments, but that not all systems with higher biodiversity will be more resilient, offers a warning that in some cases the relationship between biodiversity and ecosystem function is not sufficient to justify biodiversity protection (Thompson and Starzomski 2007). On the other hand, an excessive focus on ecosystem services instead of biodiversity per se could fail to help us achieve biodiversity conservation goals of the numerous pieces of nature that neither help nor harm us in a direct or well-known way (McCauley 2006). These may however have existence value, or they may have option value if for instance, there is a chance they turn out to have valuable properties that contribute to the resilience of a system in the face of environmental change (Lyons et al. 2005).

To what extent the choices of protecting biodiversity versus ecosystem services are likely to coincide depends on complex and yet little understood interactions between biodiversity and resulting ecosystem services (Mace et al. 2012). For instance:

- There is theoretical and empirical work that suggests a positive correlation between changes in biodiversity and the way ecosystems function (Hooper et al. 2005; Worm et al. 2006, Rey Benayas et al. 2009). For example, conservation on larger scales may result in significant reduction of carbon emissions from deforestation (Venter et al. 2009). But there is also evidence in the other direction, i.e., many ecosystem services are provided not by whole ecosystems but by functional groups of species that are either resilient to change, or easily substitutable. Consequently these services will continue to be provided despite rare species fluctuation or loss (Ridder 2008, Gaston 
and Fuller 2008; Gaston 2010). The importance of species richness, however may increase with the number of ecosystem functions considered (Gamfeldt et al. 2008).

- Many ecosystem services may be little affected by small losses of biodiversity, but changes beyond certain thresholds or 'tipping points' might result in drastic ecosystem changes (Balvanera et al. 2001). High species diversity may result in response diversity, increasing the adaptive capacity of ecosystems (Elmqvist et al. 2003).

- Finally, the effect of particular species on ecosystem functioning may vary across space and time, such that a species redundant at a particular time or space may still be important for the long-term stability of ecosystem processes (Hooper et al. 2005; Lyons et al. 2005). A more even distribution in abundance of species may enhance ecosystem functioning and increase the flow of ecosystem services (Crowder et al. 2010). ${ }^{1}$

Thus, the two choices of protecting biodiversity or protecting ecosystem services are more likely to coincide when (a) the number of ecosystem services considered increases (Isbel et al. 2011); (b) functional redundancy is important as a buffer against random natural events (Hooper et al. 2005); and (c) the focus is on stability rather than flow (Srivastava and Vellend 2005). The two approaches are less likely to coincide if species conservation only focuses on species richness, with no regard for their frequency distribution.

Emphasizing the conservation of biodiversity instead of ecosystem services may not lead to very different policy conclusions if biodiversity would just have direct, indirect and option use values (for instance, values assigned to products harvested by people, resilience and potential future uses, respectively). However, biodiversity conservation is also justified by the existence of underlying positive values that are independent of utilitarian viewpoints. These views stem in part from a recognition that biodiversity represents a form of human heritage and that the attitudes to nature are driven by feelings of responsibility or stewardship over inherited natural systems. This has been codified in the Convention for Biological Diversity stating that biodiversity should be protected also for its own sake.

In practice, for most ecosystem services the devil will be in the details; uncertainty regarding the relationship between biodiversity and ecosystem service flows, the role of biodiversity as

\footnotetext{
${ }^{1}$ Management for biodiversity conservation in delimited areas may, because of the mobility of organisms, affect ecosystem services also in surrounding landscapes (Öckinger and Smith 2007, Kohler et al. 2008).
} 
a buffer to change and the occurrence of irreversible tipping points is central to the design of successful conservation policies. In any case, focusing on conserving biodiversity at local scales for the benefit of ecosystem services may result in ignorance of conserving species of conservation concern, and it is unlikely to be enough to fulfill the ambition in the Convention of Biological Diversity to preserve species for future generations. ${ }^{2}$ Rather, synergies between conservation efforts for species per se and conservation for the benefit of ecosystem services need to be considered to make conservation cost-efficient, while many management actions still need to focus on the separate goals for conservation.

A wide variety of policy approaches can be used to enhance biodiversity conservation and increased production of ecosystem services. These comprise legal and ethical tools such as liability laws, property rights, and moral suasion; institutional innovations; command-andcontrol approaches such as product, input, or technology standards; and economic incentive approaches, such as subsidies or tax reductions for adopting desired technology and production practices, or the levying of taxes and fees on sanctioned engagement in otherwise prohibited behaviors. All of these approaches currently are employed to varying degrees. However, there exists a belief that the expansion or creation of new market-based approaches to providing ecosystem services will better achieve conservation goals by making conservation financially feasible, despite the many market failures affecting the provision of some ecosystem services (i.e., the public good nature of the services, externalities affecting their provision, incomplete information, and so on). This seems to be based on the increasing evidence of the successful use of market-based approaches in conservation schemes around the world (Landell-Mills and Porras 2002, and Pagiola et al. 2002) and that the conditions that underlie market failure are dynamic (Farley and Constanza, 2010). Indeed, in barely three decades a rapidly growing number of ecosystem functions have been characterized as services, valued in monetary terms and, to a lesser extent, incorporated into markets and payment mechanisms that are known as "payment for ecosystem services" (GómezBaggethun et al. 2010). In this Chapter we analyze the many complexities involved in the design of "optimal policies" to protect (i) biodiversity vs. (ii) ecosystem services and analyze

\footnotetext{
${ }^{2}$ For example, organic farming may result in increased biodiversity at local and farm scales thus benefitting ecosystem services such as pollination (Andersson et al. 2012), but may not be cost-efficient in preserving redlisted species (Hodgson et al. 2010, Smith et al. 2010). More generally, it has been argued that measures to preserve biodiversity in production landscapes ("land-sharing") may be inefficient as a conservation measure compared to assigning separate areas for conservation ("land-sparing") (Green et al. 2005, Phalan et al. 2012). However, it has also been suggested that the land-sharing - land-sparing concept is an oversimplification of a complex reality (Fisher et al. 2011).
} 
to what extend the criteria in (i) and (ii) set against each other or create synergies. We also analyze how payments for ecosystem services affect the relationship between biodiversity and ecosystem services conservation.

This Chapter is organized as follows. Section 2 describes the different categories of ecosystem services defined as discrete and identifiable end-products, which is in turn a prerequisite for the establishment of ecosystem markets. Section 3 analyzes the economic importance of space and time and how they affect the relationship between biodiversity conservation and ecosystem services. Section 4 analyzes the role of payments for ecosystem services as means to internalize use values derived from ecosystems and to finance biodiversity conservation. Finally, Section 5 concludes the Chapter.

\section{What ecosystem services should we preserve and how should they be measured?}

Ecosystem processes and raw materials are essential in food, fibre and bio-chemical production; they play a major role regulating air quality, climate and water, and they also provide cultural and aesthetic benefits. If ecosystem services are to provide an effective framework for natural resource decisions, they must be classified in a way that allows comparisons and trade-offs amongst the relevant set of potential benefits. According to the Millennium Ecosystem Assessment (2005), the full range of benefits from ecosystems can be organized as in Table 1.

A related question regards whether ecosystem services arising from natural resource management should be described primarily in terms of delivering a particular structure and composition of services, or in terms of maintaining a certain range, redundancy and intensity of ecosystem processes (Wallace 2007). Defining ecosystem services as discrete and identifiable end-products is necessary for quantification, which in turn is a prerequisite for the establishment of ecosystem service markets (Kroeger and Casey 2007). Indeed, the "commodification process" involves three main stages (Kosoy and Corbera 2010): i) framing an ecological function as a service, ii) assigning it a single exchange-value, and iii) linking providers and users of the services in a market exchange. Some however (including Kosoy and Corbera, 2010) have argued that this commodification might have negative ethical consequences on the way nature is perceived and the way human nature interactions are constructed. Further they argue that it has implications for unequal social relations because 
ecosystems complexity may be disregarded in order to facilitate market transactions based on a single exchange-value, which imposes a trend towards monetary, market-driven conservation. This market-driven approach is perceived to fail to account for value in a broader sense (beyond monetary value) and so obliterate other social and ecological qualities embedded in these services which are perceived at different scales by those who benefit from the ecosystem services. Furthermore, power asymmetries across those involved in price formation mechanisms would arise due to the unequal access to these services, e.g., marketdriven conservation obscures the existence of structural poverty conditions and the fact that the poor sell cheap.

The above suggests that caring for nature is incompatible with valuing nature in terms of its contributions to human well-being. However arguably there are bigger threats to both nature and to the poor than the commodification of ecosystem services. In fact many of the most destructive practices of large scale clear cutting of forests, overharvesting or monoculture cultivations are undertaken precisely to provide marketable "ecosystem services" - i.e. food and fibre - that are sold to the benefit of some private entrepreneur. One can argue that, for example, it is the lack of commodification of the standing forest - the lack of institutions, laws, and policies that enable the realization of the value of the forest in situ - that facilitates its destruction. We thus see that there is also a private/public dimension to the debate on ecosystem services and when we speak of "PES" - payments for ecosystem services - we refer typically to benefits and sometimes even payments that benefit communities and individual landowners and that encourage these communities and individuals to conserve rather than convert the ecosystem.

Valuation of ecosystem services is one piece of helpful information in the complex task of sustainably managing our natural assets. If biodiversity can be valued inherently, incorporating ecosystem services into conservation agendas becomes less of a paradigm switch and more of a shift in emphasis or an expansion. The real test, however, of whether an ecosystem service will facilitate conservation is not whether academics can evaluate the service but whether someone-or some organization - is able and willing to do what is necessary to secure it. As pointed out by Chan et al. (2007), western conservationists are clearly more willing and able to pay for biodiversity conservation than, say, African peasants (who may be willing but unable) and multinational corporations (which may be able but unwilling). 
Table 1: Categories of ecosystem service and examples of related services

\begin{tabular}{|c|c|}
\hline Type of service & Service \\
\hline Provisioning services & $\begin{array}{l}\text { Food } \\
\text { Fibre } \\
\text { Genetic resources } \\
\text { Bio-chemicals, natural medicines, etc. } \\
\text { Ornamental resources } \\
\text { Fresh water }\end{array}$ \\
\hline Regulating services & $\begin{array}{l}\text { Air quality regulation } \\
\text { Climate regulation } \\
\text { Water regulation } \\
\text { Erosion regulation } \\
\text { Disease regulation } \\
\text { Pest regulation } \\
\text { Pollination }\end{array}$ \\
\hline Cultural services & $\begin{array}{l}\text { Cultural diversity } \\
\text { Spiritual and religious values } \\
\text { Recreation and ecotourism } \\
\text { Aesthetic values } \\
\text { Knowledge systems } \\
\text { Educational values }\end{array}$ \\
\hline Supporting services & $\begin{array}{l}\text { Soil formation } \\
\text { Photosynthesis } \\
\text { Primary production } \\
\text { Nutrient cycling } \\
\text { Water cycling }\end{array}$ \\
\hline
\end{tabular}

Source: Millennium Ecosystem Assessment (2005) 


\section{Protecting Biodiversity vs. Ecosystem Services: Trade-offs across space, time, ecosystem services and irreversibility.}

Various factors affect the capacity of stocks of biological natural capital to supply ecosystem services. The biodiversity/service production function is determined by the complex interplay of biological and physical processes that vary across scales and ecosystems. For instance, in the case of regulating services (e.g., climate regulation) and supporting services (e.g., nutrient cycling), aggregate stocks of natural capital are more important than in the case of provisioning services, where the value of flows of services is most dependent on local stocks and the technology available to convert stocks into valuable supplies of goods (Vira and Adams, 2009). ${ }^{3}$ The relationship between cultural services and stocks of biodiversity is a little more complex and can vary over time; declining stocks can increase the marginal cultural values attached to surviving individuals of a particular species, suggesting an inverse relationship between the value of flows of services and the stock size, and, paradoxically for conservationists, that stock recovery may actually reduce the value of associated cultural service flows (Gault et al. 2008).

On the other hand, ecosystem management choices made by humans change the type, magnitude and mix of services provided by ecosystems. Typically, trade-offs occur as the provision of some ES are reduced as a consequence of increased use of another (Foley et al. 2005; Rodriguez et. al 2006). For instance, enhancing the provision of services such as food and timber has led to declines in many other ecosystem services, including regulating services as nutrient cycling and flood regulation. These trade-offs may be an explicit choice, but they might also arise due to the lack of knowledge about the interactions among ecosystem services that occur in space and time. When it comes to time, management decisions are often said to be too focused on the immediate provision of an ES at expenses of this same ES or other services in the future (Rodriguez et al. 2006). An economic analysis would suggest that this is particularly the case when ownership of resources is not secure, thereby reducing the incentives to plan for future benefits. A particular aspect of the temporal dimension is that there may be a degree of irreversibility that refers to the likelihood that a perturbed ES may not return to its original state if its provision actually destroys or irreversibly damages

\footnotetext{
${ }^{3}$ For example, differences in harvesting technologies can lead to different flows of outputs from similar stocks. Furthermore, though a high carbon in soils result in high biodiversity, nutrient retention and therefore a high crop production, in the short run farmers can partly compensate for reduced carbon using inorganic fertilizers and other technology.
} 
important stocks of natural capital (Scheffer 2009). When it comes to space, the analysis of spatial patterns of ecosystem services helps us to understand how the distributions of different services compare, how the value of an ecosystem service varies across an ecological and human landscape (mediated for example by patterns of human settlement, population densities, and transport costs), and where trade-offs and synergies might occur (RaudseppHearne at. 2010). However, simple mapping of ecosystem services in relation to local management practices may be an oversimplification, since the flow of many services is not only affected by the local conditions, but by the management of the surrounding landscape (Tscharntke et al. 2005).

There is a growing literature on the economic importance of space and time for biodiversity conservation and ecosystem services that we review in the following sections.

\subsection{Optimizing resource use over time and irreversibility}

Since the early 1900 authors like Hotelling and Ramsey have raised concerns on the external effects that resource depletion could have on future generations, and elaborated on dynamic optimization models to determine the allocation of resource use over time that maximize firms' profits and/or social welfare. When it comes to nonrenewable resources - that unlike renewable resources exhibit no growth or regenerative processes - the fundamental result of the seminal work by Hotelling (1931) is that the price of a non-renewable resource in a competitive market would raise at the interest rate and that the quantity extracted should continuously decline until the resource is exhausted. The simple rule was derived under very restrictive assumptions, and resource economists have developed more complex versions of the Hotelling rule, attempting to improve its empirical validity by adding more realistic assumptions. ${ }^{4}$ However, the fundamental meaning of the rule remains the same: optimality requires that resource prices reflect the scarcity of non-renewable resources. A similar story applies to renewable natural resources. Ever since Clark's famous paper on the discount rate and the extinction of animal species (Clark, 1973), it has been recognized that a higher

\footnotetext{
${ }^{4}$ For instance, Pindyck (1978) shows that exploratory activity has the effect of reducing the rate of increase of price. Moreover, extraction costs may increase inversely with the remaining stock of reserves (, with also leads the shadow price to rise less than the rate of interest over time (Farzin 1992). Instead, Andre and Smulders (2004) consider the effect endogenous technological progress in extraction showing that the path of the price follows a different trajectory (technological progress produces a U-shaped price path, yet in the long run the exhaustion effect should overcome the cost reduction effect due to technological progress, and resource prices should still increase).
} 
discount rate increases the optimal rate of exploitation of a renewable resource, and so increases the likelihood of extinction, yet latter studies have shown that the discount rate might have an uncertain effect in some circumstances (see Farzin 1974). ${ }^{5}$

What is the effect of discounting on the relationship between the focus on biodiversity versus ecosystem services' conservation? It might seem obvious that focusing on flows would benefit the present and focusing on stocks would benefit the future. In the simple world of economic textbooks, this is however not so. With correct discounting and with correct measurement of nature's stocks and flows, it would not make any difference. Optimisation of flows would take into account the need - also in the future - of intact stocks.

In reality, with poor measurement and understanding of nature, with incomplete property rights and excessively high discount rates, the choice between nature's stocks and ecosystem services will pit the interests of current and future people against one another. On the one hand, conservation efforts intended to dissipate development or resource extraction pressures in order to protect biodiversity necessarily entail costs to those local people who currently rely on such activities, in the form of a reduced flow of provisioning services. On the other hand, different categories of ecosystem services tend to change over different time scales, making it difficult for policy-makers to evaluate fully the trade-offs among them.

If uncertain property rights are the cause of current rates of overexploitation of many natural resources, we would need some policy interventions. The solution is easier said than done: establish and enforce well-defined property rights. However, the very lack of enforced property rights suggests that the government itself is either unwilling or unable to solve the problem. As discussed by Ostrom (1990), one fundamental cause may be that common pool resources have a productivity which is too low or too variable to motivate the cost of creating and defending private property rights (for instance the cost of fencing).

\footnotetext{
${ }^{5}$ We shall distinguish between two cases. First, the unit harvesting cost is independent of the size of the stock being harvested. Here, the optimal rate of rate of exploitation is determined by the requirement that the marginal growth rate of the resource be equal to the discount rate; a higher discount rate raises the optimal rate of exploitation and lowers the optimal standing stock for a resource with a concave growth function. Second, is there is a stock-dependent unit cost of harvesting (a positive "stock effect"). Here the discount rate plays a dual role. It represents the required rate of return on a growing asset, leading to smaller standing stock when it increases, but also the opportunity cost of capital to be invested in harvesting equipment (a higher discount rate thus means more costly harvesting, which in turn implies a less intensive optimal harvesting and a larger standing stock). Hence, the discount rate is active in both of its roles simultaneously, and its effects on optimal harvesting and standing stock would depend on the capital intensity of the harvesting process and the cost of capital (Hannesson 1987).
} 
Inertia strongly influences the time frame for solving different ecosystem-related problems. For example, supporting services such as soil formation and primary production and regulating services such as water and disease regulation tend to change over much longer time scales than provisioning services. Agricultural intensification results in a slow loss of soil biodiversity with negative consequences for productivity, but may be compensated by increased used of agro-chemicals (Giller et al. 1997). As a consequence, impacts on more slowly changing supporting and regulating services are likely to be overlooked in pursuit of increased use of provisioning services (Millennium Ecosystem Assessment 2005).

A related aspect of the temporal dimension of the management of natural resources is irreversibility. Despite most of the time, change in ecosystems and their services is gradual and incremental (and detectable and predictable, at least in principle), there are many examples of nonlinear and sometimes abrupt changes in ecosystems. In these cases, the ecosystem may change gradually until a particular pressure on it reaches a threshold, at which point changes occur relatively rapidly as the system shifts to a new state. For instance, some coral reef ecosystems have undergone sudden shifts from coral-dominated to algae-dominated reefs. The trigger for such phase shifts - which are essentially irreversible (at least on the timescales traditionally used in economic planning) - is increased nutrient input leading to eutrophic conditions, and removal of herbivorous fishes that maintain the balance between corals and algae. Once a threshold is reached, the change in the ecosystem takes place within months and the resulting ecosystem, although stable, is less productive and less diverse.

Tipping points concerning ecosystem services mediated by biodiversity change may be caused by multiple drivers such as land-use change, climate change, overexploitation and pollution. Tipping points occur when effects of global change are augmented by positive feedbacks, when there are thresholds beyond which shifts to alternative stable states occur, when changes induced by drivers are long-lasting and hard to reverse and there are significant timelags between dynamics of drivers and the expression of impact on the system (Leadly et al. 2010). For example, a linear loss of biodiversity may, through loss of keystone species or loss of key functional groups, result in abrupt non-linear changes in ecosystem functioning and therefore the flow of ecosystem services (Chaplin et al. 2000). Habitat loss may result in sudden extinction of species when critical thresholds are reached (Hanski 1999). Pollinator loss may result in parallel loss of pollinated plants (Biesmeijer et al. 2006), which may feed 
back on the population dynamics of the pollinators. Empirical studies have confirmed the existence of tipping points in different ecological systems (Scheffer et al. 2001, Leadly et al. 2010). When there are alternative stable states, the process of change may be difficult to reverse (Sheffer 2009, and Leadley et al. 2010). For example, when change results in species extinctions, this may cause change to become irreversible unless the species can recolonize from elsewhere. In spite of much evidence, it should be pointed out that experimental evidence demonstrates that alternative stable states are but one of out of several ways in which ecosystems can respond to change (Schröder et al. 2005), and that it is a major empirical question to determine the extent of alternative stable states in real ecosystems.

Regime shifts affect the services that people derive from ecosystems. Capabilities for predicting some nonlinear changes are improving, but for most ecosystems and for most potential nonlinear changes, while science can often warn of increased risks of change, it cannot predict the thresholds where the change will be encountered. Marginal changes in management methods could thus have huge effects on some ecosystems and on future management opportunities. Due to multiple steady states, several strategy paths may fulfill marginal conditions derived using optimal control theory or dynamic programming, but some of them may be suboptimal (Crepin 2007).

The presence of thresholds, combined with uncertainty motivates precautionary approaches because social planners must account for the option value associated with the system's future potential production of goods and services. The economics literature (Arrow and Fisher 1974, Henry 1974, Epstein 1980, and Freixas and Laffont 1984) shows substantial evidence of an irreversibility effect - risk neutral and risk adverse agents should act more carefully to prevent future irreversible risks if more information is expected to be available in the future. Thus, the existence of biodiversity-related alternative stable states, suggest that we should determine boundaries for the degradation of biodiversity that should not be passed (Rockström et al. 2009) $)^{6}$.

Finally, it has been argued that renewable natural capital, such as biodiversity, cannot be treated in the same way as manufactured and financial capital (Blignaut and Aronson 2008). The reason is that the value of natural capital will not erode over time. Furthermore, the cost

\footnotetext{
${ }^{6}$ It has also been pointed out that proposing a boundary may increase the risk of prolonged degradation if, in fact, conditions continue to degrade also before the proposed threshold is reached (Schleisinger 2009).
} 
of restoring biodiversity may be larger in the future than today. Therefore, the value of remaining natural capital (biodiversity) must increase by at least an equivalent degree as the rate of depletion. Hence, biodiversity as a natural capital may need to be valued using a negative discount rate. When conserving biodiversity for its own sake, this is not related to an economic argument, but to an ethical one, as for example codified by the Convention of Biological Diversity. What is the value of a conserved species in the future, when it comes to ethics? It is hard to envision that the value should be less, if anything it will be higher due to fewer species existing in the world (with all likelihood). It has been argued that other approaches than economic arguments may not be applicable for the conservation of species out of ethical reasons, but that other approaches such as safe minimum standard approach should be preferred (Bulte and van Kooten 2001).

\subsection{Scale and Spatial Models of Ecosystem Services}

Scale may influence the management of biodiversity for ecosystem services for two major reasons. First, ecological processes may be scale-dependent necessitating management at scales larger than for example an individual property. If relevant biodiversity only responds to management at large scales then actions of property owners need to be coordinated (Zang et al. 2007). Second, if the effect of biodiversity conservation occurs at a larger spatial scale than the individual property or is displaced from the individual property, there may be little incentive for the land-owner to benefit biodiversity to promote ecosystem services (Lant et al. 2008; Fisher et al. 2009). For example, promoting crop pollination by enhancing the abundance and diversity of pollinators may require incentives in the form of agri-environment schemes and coordination of the action across several farms.

Moreover, since the internalization of environmental externalities generally relies on political institutions, and since these tend to be most responsive to local concerns, externalities that involve immediate local costs will tend to be addressed before externalities generating costs that occur in the future at distant locations (Barbier 1997). Furthermore, the value of local conservation may well differ among countries due to different income levels. Indeed, evidence has shown that biodiversity conservation has been especially challenging in the poorest countries, partly because conservation through the designation of protected areas has often adversely affected the people displaced in the process. Even though Integrated Conservation and Development Projects (ICDPs) have been implemented to address this 
problem by including compensation for those who have lost access to resources due to the biodiversity conservation, they have lead to mixed results (Tallis et al. 2008, Coria and Calfucura 2012).

On the other hand, the local benefits yielded by global biodiversity conservation are closely connected to the productivity of managed agricultural or forest land. Since the proportion of the population that directly depends on agriculture is generally highest in poor countries, the localized consequences of global biodiversity conservation (both positive and negative) are generally expected to be greatest in those countries (Perrings 2007). In some sense, the main international mechanism for making payments for biodiversity-related development assistance, the Global Environment Facility, was established precisely to cover the global interest in local conservation. The concept of incremental cost, which in principle determines payments made by the GEF, is a measure of the difference between the cost a country would be prepared to bear in the provision of an environmental public good and the cost of meeting global demand for the same public good. As pointed out by Perrings and Halkos (2012), the fact that the GEF is widely regarded by scientists as underfunded is an indication that donor countries have a lower estimate of the incremental cost of local conservation than the scientific community.

Policy makers often implement explicitly spatial polices that recognize the spatial nature of biodiversity and ecosystem services, taking into account, for example, sizing and siting of protected areas; edge effects; and corridors. As an example, the SLOSS debate (single large or several small) addressed the impact on biodiversity conservation of protecting a single large reserve as against several smaller reserves. Larger reserves have the benefit of supporting more species (species richness) than a number of small reserves of the same total area and so were thought to be better for biodiversity conservation. But more recently some have argued that, depending on the extent of and nature of spatially correlated risks, having several smaller reserves can spread the risk of not losing a species entirely if fire, disease, or pests wipe out one protected area (Busby et al. 2012), and many small reserves may better capture spatial variation in ecological conditions (Moilanen et al. 2009, and Tscharnkte et al. 2002).

Even where ecosystem services and biodiversity conservation are scale neutral, edge effects and fragmentation may well be an issue. Borders of protected areas can become sinks and so the ratio of perimeter length to area of the reserve becomes important, particularly for fauna 
with wide ranging areas (Woodroffe and Ginsberg, 1998). Fragmentation increases considerably the ratio of de facto perimeter to area and is believed to be a key driver of biodiversity loss (Busby et al. 2012). (On the other hand the "perimeter" may also be positive from the viewpoint of human access to ecosystem services or the flow of ecosystem services from the reserves into other the surrounding landscapes (Smith et al. 2010)). Fragmented patches of habitat may exhibit lower resilience and therefore reduced potential to provide ecosystem services. Corridors are a spatial policy that enable the creation of an integrated network of protected areas and therefore reduce inter-reserve fragmentation (Leal et al. 2005). Wildlife corridors are increasingly seen as an important approach to conserving biodiversity (Lindenmayer and Nix, 1993, Gilbert-Norton et al. 2010, and Hodgson et al. 2011), or to reintroduce biodiversity such as into large-scale agro ecosystems that have lost their natural vegetation (Altieri, 1999).

Much of the ecological-oriented literature has in the past implicitly ignored how people react to policy and the feasibility of regulations over access to and use of reserves. For example, when a protected area or reserve is planned, and indeed most of the SLOSS debate, there is an implicit assumption that planners can achieve what they want to achieve - that is, that there is going to be full compliance with choices over boundaries and access rules. Further, only recently has the issue of displacement of anthropogenic activities from a protected area to less protected areas been included in analyses of the effectiveness of efforts to protect biodiversity and ecosystem services.

These changes in people's behaviour as a response to environmental policy are reflected in terms of labour allocation, what resources and what quantities households collect, and which forests and which areas of forests are used, implying that the spatial pattern of resource extraction is likely to be changed, not just within the confines of the particular protected area, and therefore the spatial pattern of biodiversity and ecosystem services from the landscape as a whole. Changes in spatial patterns of biodiversity measures and ecosystem services are therefore often the result of human activities that are responses to policies that may not themselves be explicitly spatial. And because human actions change landscapes, and therefore implicitly patterns and qualities of biodiversity and the ability of those landscapes to provide ecosystem services, it is important for policy makers to understand how their policies influence human decisions to alter those landscapes and so predict spatial patterns of human responses (Bockstael, 1996). 
Rural households, particularly in low-income countries, tend to be highly dependent on the local resource base, both for extractive - and therefore ecosystem degrading - and nonextractive ecosystem services. These households might collect fuel wood from a nearby forest; earn a livelihood from fishing; or hunt bush meat for home consumption and for sale. Typically policies designed to protect biodiversity and ecosystem services in such areas place a burden on these resource-dependent local communities. Indeed if such policies did not affect local people, and did not affect how these people interact with the resource base, then arguably the policy either would not be needed or would not be effective. Amani Nature Reserve in Tanzania is an example of an area that according to national regulations must be protected from any extraction within its boundaries (Burgess and Rodgers 2004). However, the Amani management committee recognised that villagers did not have access to alternative forests from which to collect the non-timber forest products such as fuel wood that were essential to their livelihoods, nor space and resources to plant trees on their own land. The management therefore introduced a de facto buffer zone within the reserve boundaries, reducing the effective size of the reserve, but recognising the reality of the socio-economic setting and landscape within which the reserve is situated (Robinson et al., 2011).

Spatial analyses of natural resource use often take as a starting point the impact of distance costs on human activities that affect biodiversity and ecosystem services. Von Thunen's theoretical model of optimal land use across a landscape has often been taken as the natural starting point for many of the explicitly spatial analyses of deforestation (Chomitz and Gray 1986, Nelson and Hellerstein 1997, and Pfaff 1999). The concept comes from economic geography and develops a simple one-dimensional linear landscape in which the relative costs of transporting different agricultural commodities to a central market determine agricultural land use around a city. Economic rents to particular land uses vary with location even with homogeneous resources because market access costs are a function of distance from markets. This model has been used to explore the forest-agriculture margin under different policies. Although a relatively simple concept, much of the empirical deforestation literature finds that better road access and shorter distance to towns correlates to lower levels of forest cover, which implies that patterns of forest cover correspond to patterns of roads and cities. Ahrends et al. (2010) apply such a framework to forest degradation in Tanzania. They find timberinduced degradation in a ring closer to Dar es Salaam with a wider concentric ring of NTFPinduced degradation (that includes charcoal) further away from the city. 
Key to research that builds off the von Thunen framework is that transport costs are central to spatial economics, and that location matters, whether that involves getting produce from farm to market, bringing fuelwood from the forest to the hearth, or transporting charcoal to urban centres of demand. These approaches may not be explicitly spatial, but they typically have a spatial implication/consequence. Importantly, this framework predicts that distance matters for how people interact with ecosystems. In empirical papers distance from village to resource often emerges as a significant determinant of how much forest biomass is collected (Sills and Abt, 2003, and MacDonald et al. 2001). Distance to markets also is often significant, reflecting in the literature a recognition that forest product markets are far from perfect, often modeled with the inclusion of some discrete fixed cost to market access (Omamo 1998, Key et al. 2000, and Robinson et al. 2002 and 2008).

There have been far fewer attempts to link spatial policies over natural resources to the impact on biodiversity and the resulting ecosystem services provided by the particular resource that takes into account the spatial reaction of people to such policies. A number of papers recognize explicitly that rural people's response to a policy can change the pattern, and therefore value, of ecosystem services, though this link is not always made explicit. For example, several papers highlight the impact of a spatial exclusionary policy (such as the reclassifying of a forest as a REDD forest) on the spatial pattern of forest degradation through "leakage", the neighbourhood displacement of activities from that newly designated REDD forest to less protected forests. The protection of one particular forest patch is increasingly recognized to have the potential to result in the displacement of some extraction from the now-protected area to less-protected forest areas. For example, there is empirical evidence of an "intensification" of resource use in a peripheral zone outside of a park in Madagascar (Ferraro 2002). Lokina et al. (2008) find evidence of such forest deterioration in unprotected forests following the re-enforcement of Tanzania's restrictions on access to governmentowned "preservation" forests. Lewis (2002) suggests that depending on the type of ecosystem, "concentrating previously dispersed activities into certain parts of the forest may actually increase the negative ecological impact". That is, the policy of protecting a forest from human degradation and deforestation may at a landscape level have a negative impact on the overall provision of ecosystem services. 
How this displacement of activity affects the ecosystem services provided by a particular forest or landscape of forests depends not only on how people change their spatial interaction with the landscape, but also how that change translates into the ecosystem services provided by the landscape. Robinson et al. (2011) introduce the explicitly spatial concept of an "ecological damage function" (EDF) that maps the spatial degradation of the resource into loss of ecosystem services. In their paper a very simple model is employed which assumes that there is one resource providing one ecosystem service. The authors identify four EDFs that reflect stylized representations of ecosystems in practice. A pristine-only EDF values only fully-protected ecosystem and so represents the most extreme of EDFs in which any degradation renders the particular area where the degradation occurs without ecological value: this is therefore the most extreme threshold. In contrast the biomass-proportional EDF values the total amount of biomass and not it's spatial location, and so is perhaps most relevant to carbon sequestration. The ecosystem services EDF provides less value per unit of biomass if it is degraded but does not lose its value entirely. The eco-threshold EDF recognizes that limited degradation may cause limited ecological damage, but there is some threshold of degradation below which the ecosystem services provided by the protected area fall off rapidly. Many ecosystem services display this kind of non-convexity. As examples, hydrological benefits have been found to be insensitive to slight degradation but there is a point at which a highly degraded forest makes little contribution to water flow (Wu and Boggess 1999, and Robinson et al. 2011). It is likely that for a particular forest or protected area there are multiple ecosystem services and each maps through a different EDF into a different level of ecological damage.

Protected areas are one of the key policy tools for biodiversity conservation. And indeed many studies of protected areas have found that they are effective at reducing degradation and therefore by implication protecting biodiversity and ecosystem services - within their boundaries. But these studies have typically simply considered whether resources within a protected area are more or less degraded than those outside. Yet unless those protected areas have been located randomly, the results are open to bias (Andam et al. 2008). Policy makers that want to maximize the impact on deforestation might choose areas most at threat to locate new reserves; whereas policy makers that want to ensure that protected land remains forested might choose those locations where there is least anthropogenic threat (Pfaff et al. 2009). Similarly, the choice of biodiversity measure is likely to influence reserve location. For example, if valued species are a key indicator then lands that face a lower pressure might be 
chosen. Globally, less-threatened land has tended to be where reserves are located (Joppa and Pfaff, 2009). There might also be a choice between pure species numbers (which might be highest in some inhospitable swamp) or protecting "charismatic" species with beauty and viewing value such as found in tiger or panda reserves.

Sizing and siting decisions tend to have different drivers in high-income and low-income countries. In high income countries costs of purchasing land can change the optimal pattern of conservation (Andam et al. 1998). But in low-income countries how well markets for labour and forest products function influences how people react to a protected area and therefore the anthropogenic pressure on a protected area and the relative costs of protecting a particularly located and sized reserve. Robinson et al. (2011) show conceptually that where markets function well people can more easily switch from reliance on resources inside a protected area to wage and product markets. But when markets do not function so well people are likely either to substitute resources found outside the protected area or simply to continue to use it, albeit now illegally. Biodiversity-rich areas located in remote areas may be subject to fewer pressures from markets and human population. But if rural communities are highly dependent on resources found in these areas, it may be hard to site a reserve because these communities have few alternatives to using the resources found in a proposed reserve. In general, how people react to a protected area, and therefore its effectiveness, is influenced by marketswell-functioning markets allow relatively easy substitution from the protected area to the market.

Buffer zones are an example of an explicitly spatial policy designed to meet the dual goals of protecting park resources and possibly the biodiversity within the park whilst also providing benefits to nearby households (Wells and Brandon 1992, Naughton-Treves et al. 2005, and Dudley, 2008). The UNESCO Biosphere Reserves are a specific example of spatial policy to achieve multiple aims. The reserves comprise three adjacent areas, a core zone, buffer zone, and transition area that each has different roles with respect to conservation and livelihoods. Yet there has been little use of spatial models to inform the optimal size and access/management rules for buffer zones that take into account how people respond to the spatial pattern of reserve and buffer areas (Robinson et al. 2011).

The protection of biodiversity requires enforcement of access rules, and in low-income countries that enforcement is often limited by scarce resources or a lack of political will and 
so rarely perfect (Albers 2010). Yet to date economists have made very little contribution to addressing the role of enforcement in driving spatial patterns of degradation and fragmentation of habitats. Albers (2010) and Robinson et al. (2011) demonstrate that when enforcement is imperfect policy makers may be better off concentrating that enforcement effort into a smaller reserve surrounded by a buffer zone where extraction of resources is permitted, rather than trying and failing to fully protect a larger reserve. These papers are based on the idea that there is a strategic interaction between those with a limited budget responsible for protecting a reserve and those who have traditionally (albeit illegally) extracted from that reserve.

Sims (2011) provides a rare analysis of the interaction between protected areas and spatial patterns of protecting those reserves and the spatial patterns of fragmentation that result from the interaction of illegal extraction and imperfect enforcement. Her research shows how the spatial pattern of enforcement affects the level of fragmentation within a protected area. For example, enforcement that is concentrated along the boundaries of a park may push illegal clearing further into the interior of a protected area thereby increasing fragmentation. Fragmentation in reserves therefore results from the inability of policy makers to enforce access restrictions perfectly and a lack of understanding as to how spatial patterns of enforcement affect fragmentation.

\subsection{Ecosystem Services' Bundles}

Interactions among ecosystem services occur when multiple services respond to the same driver of change or when interactions among services themselves cause changes in one service to alter the provision of another. The linkages among ecosystem services are not fixed, but can shift through time due to policies that address ecosystem services. For example, afforestation for carbon sequestration is a potential strategy for the mitigation of global climate change in regions of the world where the net carbon storage of a tree plantation would be greater than that of the ecosystem it replaces. The Kyoto Protocol's Clean Development Mechanism (CDM) provides economic incentives for afforestation by allowing countries to offset a portion of their greenhouse gas emissions through carbon sequestration projects. However, afforestation may have negative impacts on other ecosystem services including water supply, soil fertility, and biodiversity values (Chisholm 2010). Furthermore, in some cases, we are not limited to simply responding to existing synergies and trade-offs, but can 
actually manage ecosystem strength and even their existence. For instance, creation of riparian buffers alters the trade-off between agricultural production and water quality by limiting the effect of the driver (fertilizer use) on water quality, but has hardly any effect on the impact of the driver on agricultural yields (Bennett et al. 2009).

"Bundling" ecosystem services refers to merging multiple values from a piece of property under a single credit type. For example, if a landowner restores an area of riparian forest, it results in improvements to more than one ecosystem service, including reducing stream temperature, improving wildlife habitat, sequestering carbon and mitigating potential floods. Bundling allows these services to be sold under a single credit type-e.g. an ecosystem credit - and it might provide a way for landowners to get paid for the broader benefits they are providing (Deal et al. 2012). Understanding the interactions among ecosystem services is, however, a necessary precondition to bundling, yet a fundamental problem is the lack of understanding of where trade-offs and synergies among ecosystem services might occur. This suggests that a critical area of research in ecosystem services includes studies that identify common sets of correlated ecosystem services and the situations (landscapes and management regimes) in which they typically occur. Once such bundles have been identified, research to understand the mechanisms behind their grouping (e.g. are the services responding to the same driver or are they interacting) can help us better manage the relationships among ecosystem services, designing bundles that reduce the tradeoffs and create synergies in addition to simply avoiding or taking advantage of them where they already exist (Bennet et al. 2009). For example, Raudsepp-Hearne et al. (2010) identified patterns of interactions among 12 ecosystem services (including provisioning, cultural and regulating services) in Quebec, Canada. They perform a principal component analysis of the variations in the set of ecosystem services concluding that more than half of the ecosystem service variance could be explained through two components. The first component corresponded to an ecological gradient that varies from fully forested land to fully agricultural land and explained $34 \%$ of variance. The second corresponded to social gradient - ranging from tourism and recreation on one end to pork production and deer hunting on the other- explained an additional $17 \%$ of ecosystem variance. Furthermore, they find strong trade-offs between provisioning and both regulating and cultural ecosystem services in a peri-urban agricultural landscape. In their landscape, food production in areas with low regulating ecosystem services was not affected by these trade-offs, but the loss of soil-regulating services was costly to farmers that have to replace these services, tourism operators that have to suspend water recreation, and 
governments that have to pay for water-quality treatment and improvement. Compared to previous literature, they found a much larger negative correlation among ecosystem services, which seems to be linked to the scale of the study and the set of ecosystem services analyzed.

Townsend et al. (2011) highlights the impact of reforestation on water supplies, and the value of bundling payments for environmental services (PES) from watershed restoration, including water quality improvement and carbon sequestration coupled with wood production. They compare the net returns of reforestation and bundling to the value of existing agricultural land-use of 408000 ha of the Warren-Tone watershed (WT) in south-western Australia. A hydrological model (LUCICAT) was used to define the relationships between reforestation/deforestation and water yield and quality, thus providing a basis for valuing the hydrological benefits of reforestation. Various land-use change scenarios were examined; with modeling indicating more than $70 \%$ reforestation is required to restore stream salinity to a potable threshold. They conclude that reforestation was unprofitable when only wood revenues were considered with a discount rate of $9.5 \%$, but was profitable at carbon prices of at least $\$ 22$ t CO2-e. For the latter, reforestation activities driven by the economic benefits from selling wood and carbon, generate an externality benefit in the form of improved water quality without the need for any additional payment to landholders. However, payments for activities that lead to improvements in water quality could represent a new, additional source of income for landholders on the proviso that there is sufficient reforestation to reach the potable threshold. Alternatively, costs could be imposed on those whose land-use practices cause the release of salt into waterways.

\subsection{On the need for multiple policy instruments}

Biodiversity and ecosystems provide goods and services with a mix of values, some of which are tangible and marketable, whereas others are of a public or common good nature. It is not surprising that the use and non-use values associated with biodiversity and ecosystems will require different policy instruments. Direct use values, especially when reflecting provisioning services, are privately appropriable, and can often be addressed with economic instruments. Indirect use values reflecting regulating services such as water regulation and purification, and non-use values, including existence values and many cultural services provided by ecosystems, are more difficult to address, since due to their public good nature, 
markets would lead to insufficient provision. Uncertainty, irreversibility, and biodiversity hotspots complicate the problem even more as they require the design of more sophisticated instruments that ensure that the boundaries for the degradation of biodiversity as a whole and in vulnerable areas are not passed. Moreover, even if we leave the question of market failures to one side, we would expect to find differences in the socially optimal level of biodiversity conservation in different countries due to differences in national income, species richness, threats to biodiversity and conservation infrastructure (Perrings and Halkos 2012), and hence in the stringency of policy instruments for biodiversity conservation across countries.

Due to the mentioned features of the biodiversity conservation problem, it is clear than a single policy instrument is unlikely to achieve optimality. We need a combination of policies to ensure both the protection of the flows and the stock. Furthermore, due to multiple market failures, coordination of policies to address the interaction of these failures will often be more efficient that policies that address these failures separately (Bennear and Stavins 2007).

The ecological, socio-economic and political constraints of conservation are so difficult to address that there is no generic "optimal combination of instruments", as they will vary depending on the type of ecosystem service, time and context. Nevertheless, if we build on traditional evaluation criteria, the mixes should promote conservation effectiveness and efficiency to the largest extent that is possible. In order to promote political feasibility, they should minimize social impacts and be compatible with the institutional frameworks in place. Clearly, this is easier said than done. However, the focus on ecosystem services might help in the task of strengthening the conservation of biodiversity; the current Conventions about Biodiversity are framed in terms of avoiding species loss instead of bringing biodiversity back to reasonable levels. Protecting the flow as well as the stock could be both more relevant to human needs and also more effective as it implicitly means that you would not allow the stock to go under a threshold.

On the other hand, it is important to keep in mind that biodiversity conservation and ecosystem service management are already subject of different policy mixes that do originate from the interaction of environmental policy and different sectorial policies aiming at increase the provision of certain types of ecosystem services. In most instances these sectorial policies have negative impacts on biodiversity conservation through, for example, infrastructure development, clear cutting of forest to provide land for agriculture, and subsidies for the 
extraction of raw materials or for energy or fuel that consequently lead to higher impacts on the environment. It is ironic that in reality one of the most relevant issues for biodiversity conservation is not subsidies for conservation but the prevalence of perverse subsidies for overexploitation. Perverse subsidies are so common that subsidy removal is actually classified as an environmental policy instrument (Coria and Sterner 2011).

\section{Payments for ecosystem services and biodiversity conservation}

As mentioned above, payments for environmental services (PES) are increasingly becoming subject of national and international development strategies as means to finance biodiversity conservation. For instance, the need for explore innovative financial mechanisms for the implementation of the Convention of Biological Diversity and its 2010biodiversity targets was explicitly established in the Millennium Ecosystem Assessment (2005). This section starts with a brief description of the concept, and it continues with a discussion of the use of PES in agricultural lands and forests, before dealing with current practical design issues.

Regarding the different types of payments for ecosystem services, Scherr et al. (2004) classifies them in four categories:

(i) Public payment schemes, where the local authorities or the government decide which ES are priorities for conservation and implement payment schemes targeted to preserve these services. Examples include conservation easements (guarantees that such land will not be logged or farmed); programs to co-finance investments in conservation efforts; and the PES system in Costa Rica.

(ii) Open trading under regulatory cap or floor, where a government defines a mandatory level of a specific ecosystem service to be provided, but to achieve this level, the regulated party can decide whether to directly comply or to compensate by paying others who are in the position to supply the service more cheaply. The most developed program is for wetland mitigation under the Clean Water Act of 1972 which lead to the development of numerous wetland mitigation banks in the US (Bayon 2006).

(iii) Self-organized private deals involving closed transactions between offsite beneficiaries and service providers. Examples include the deal between the Costa Rican National Institute 
of Biodiversity (INBio) and Merck, Sharpe, and Dohme, Inc. The agreement called for INBio to provide Merck with plant, insect, and microbiological samples that could be tested for biological activity in exchange for up-front payments to INBio, training opportunities for Costa Rican scientists at Merck facilities, collaborative projects with Costa Rican universities, transfer of processing technologies to INBio, and royalty arrangements developed in the event that marketable pharmaceuticals resulted from the collaboration.

(iv) Eco-labeling, whereby the ES component is embedded in a traded product; Producers sell products produced under a management system certified to enhance environmental service provision. Examples include the Forest Stewardship Council wood and non-wood certification. However, some consider eco-labeling as not being a kind of PES since it bases on a different mechanism to induce sustainable use of biodiversity (Wunder 2005).

Assessments of PES schemes find that most current schemes tend to be local level arrangements. In contrast, large-scale PES schemes are mainly government driven, working at the state, provincial, national level and international level, with some of them being part of the carbon sequestration markets created by the Kyoto Protocol on Climate Change, as for instance, REDD and CDM. A major challenge to implement large-scale PES schemes is that the ecosystem services that they target are non-excludable. ${ }^{7}$ For instance - as discussed previously - some of the ecosystem services provided by biodiversity, such as climate regulation, are pure public goods, and it is impossible to exclude anyone from benefiting from them. In addition, the climate regulation both spans local and global scales and is omnidirectional. For addressing non-excludability we require instead collective institutions based on cooperation - instead of competition - that either create the conditions required for private sector payments, or accept the public good nature of the services and pay for them directly. Cooperation should be at the same spatial scale over which the service is provided (Farley and Constanza 2010).

\footnotetext{
${ }^{7}$ Non-rivalry can be also a challenge, as many local, regional and global services are open access. The implementation of market-based mechanisms requires "propertization". That is, the creation of property rights where none currently exist. Therefore, the first implicit step for implementing market-based mechanism is for the "collective" institution to declare property rights for itself so that it can then determine the supply of the services available. The next step is to distribute the property rights: who has the right to the resource and for how long. Unfortunately, propertization will only take account of the non-rival character of many ecosystem services, since unlike non-rivalry, non-excludability is inherently a physical characteristic and not a policy variable.
} 
Today, most PES projects have focused on one or more of the following services: biodiversity, carbon and water regulation, or landscape beauty. Furthermore, there is only a limited number of PES projects in the developing world, but the number is rapidly increasing through national programs (that tend to be government driven) to local PES projects (which are smaller and tend to be financed by the private sector), (Wendland et al. 2010). In what follows, we describe the use of PES for preserving these ecosystem services in agricultural lands and forests.

\subsection{Payments for Ecosystems Services in agricultural lands and forests}

Agri-environmental policies (AEPs) in the United States and the European Union are examples of payments for environmental services. The programs sponsor environmental services targeted at reducing negative externalities, such as nutrient run-off and soil erosion and an increase in positive externalities, such as scenic vistas, and preserving of farming heritage (Baylis et al. 2008). United States began providing payments to farmers to protect soil and reduce the production of certain crops in excess of supply in the 1930s, while in Europe AEPs were not developed until the 1980s (Baylis et al. 2008). Even though the motivations for AEPs in the two regions are similar, there are some important differences regarding the services targeted by the programs. For instance, the bulk of U.S. conservation expenditures target the reduction of the negative externalities produced by agriculture. Thus, until the mid-1980s the focus was preventing the loss of topsoil, but it has been widened since then to incorporate the reduction of agricultural water pollution, as well as ensuring that farming does not result in the draining of wetlands and the loss of wildlife habitat (Baylis 2008). Instead, the EU has taken a wider view including not only negative externalities but also many aspects of traditional farming that are perceived as desirable outcomes. For instance, the Environmentally Sensitive Areas (ESA) program, launched in the United Kingdom in 1986, was the first agri-environmental program in the European Union (EU). The ESA program was intended to protect valued landscapes and habitats and to improve public enjoyment of the countryside through long-term (usually 10 years) voluntary agreements between the government and farmers. Environmental services purchased under the ESA program included improved habitat for birds, biodiversity (such as in species rich grassland), landscape beauty and historic preservation (Dobbs and Pretty 2008). Furthermore, there are differences in the way that negative externalities are addressed in these two regions: whereas U.S. policy focuses mainly on the by-products of extensification - that is, the use of excessive 
amounts of environmentally sensitive land - EU AEPs focuses mainly on by-products of intensification of farming - i.e., the use of too many non-land inputs per unit of land.

Regarding PES aimed to avoid deforestation and/or encourage afforestation, Costa Rica pioneered the use of formal PES mechanisms by establishing a country-wide program called Pago por Servicios Ambientales (PSA) in 1997, which aimed to reverse the severe deforestation rates existing at that time (Pagiola, 2008). To date, a growing number of PES like mechanisms are spread thought the world and international cap and trade programs, such as Reduced Emission from Deforestation and Degradation (REDD), are in place to articulate international PES schemes.

\subsection{Key Design Issues}

An important challenge related to the implementation of PES is the existence of important information asymmetries (Ferraro 2008). These asymmetries arise since landowners have better information than the conservation agents about the opportunity costs of supplying environmental services when negotiating the contract (adverse selection). Furthermore, since it is costly to monitor contract compliance, the landowners have fewer incentives to fully fulfill the contractual responsibilities (moral hazard). Indeed, in the European Union, large efforts have been spent to monitor if farmers fulfill the contracts for receiving agrienvironment schemes. Unfortunately, less effort has been spent on evaluating their efficiency in protecting biodiversity and ecosystem services.

Furthermore, as long as participation is voluntary, payments are flat and there is a big deal of variation in the opportunity costs of supplying environmental services, PES would led to a concentration of contracts on unproductive lands run by farmers with le lowest land use intensities (i.e. lowest opportunity cost), a problem known in the literature as "adverse selection". Indirect evidence of adverse selection is found in most AEPs. For instance, several major evaluations of the ESA program conclude that the program was effective in enrolling many farmers in the entry-level contract tiers, but the scheme did not generally offer sufficient economic incentives to attract high levels of enrollment in the intensive farming areas; incentives offered induced enrollment of a substantial fraction (40\%-90\%) of farmers in eligible areas characterized by grazing and less intensive agriculture, but enrollment was lower in areas characterized by more intensive arable production (Dobbs and Pretty 2008). 
This pattern of participation suggests that environmental benefits coming from AEPs are primarily in the form of preserving environmental features already in place: monetary incentives were adequate to arrest intensification in more marginal areas where it might not have been profitable to increase the level of intensification anyway, but insufficient to reverse intensification in more productive arable areas (Kleijn and Sutherland 2003, Kleijn et al. 2001, Rundlöf and Smith 2006, Kleijn et al. 2006). There is also evidence that some of the schemes affect biodiversity at local scales, but few studies have linked local conservation effects to national trends in biodiversity (Kleijn et al. 2011).

The previous evidence does not mean that AEPs do not provide net benefits, but the schemes were limited in their success in enrolling farmers in higher payment tiers, tiers that required more substantial changes in farming practices. Furthermore, an important reason for limited success of AESs is that the landscape context of agri-environment schemes is not considered (Kleijn et al. 2011). As a consequence, the uptake of schemes, as organic farming, is largest in regions where the opportunity cost is lowest and not where the effect on biodiversity is largest (Rundlöf and Smith 2006). It is also not always clear if the goal of agri-environment schemes is to promote local biodiversity for the benefit of ecosystem services or national biodiversity for conservation per se. For example, organic farming may promote local biodiversity more in intensively farmed regions, but be more important for rare species in less-intensively farmed areas (Smith et al. 2010).

Similar evidence has been found in the case of Costa Rica. For instance, Ortiz et al. (2003) find that $76.8 \%$ of the forest area under PSA contracts would likely have been conserved or managed with limited forest interventions in the absence of PSA. Hartshorn et al. (2005) also find more than $70 \%$ of PSA forest protection contracts to be on land with production capacities that only allow forest management/protection (51\%), or severely limited agriculture (20\%). Pfaff et al. (unpublished) find that annually only $0.08 \%$ of the PSA contracted forest would have been cleared in the absence of payments. Finally, Sills et al. (2006) detected statistically significant but very small effects on land-use patterns between PSA and non-PSA land.

Paying for forest protection on land that requires no protective measures is an inefficient use of scarce conservation funds (Wünscher et al. 2008). This means that the success of PES promoting conservation largely depends on the programs' ability to encourage clear additionality. However, additionality is not a selection criterion in most PES programs, 
though they could clearly benefit from improved spatial targeting. Babcock et al. (1997) classify targeting approaches for conservation programs into those that target (i) benefits, (ii) costs, or (iii) benefit-to-cost ratios. Wünscher et al. (2008) empirically test the potential of the targeting tool to boost the financial efficiency of PES programs in Costa Rica in terms of expected additional environmental services (benefits) per dollar spent. They address three kinds of possible inefficiencies: (i) the desired land-use activity would be adopted even in the absence of payments; (ii) the payment is not high enough to lead to the socially desirable land use; (iii) the payment encourages a land use with positive externalities that are worth less than the cost. They address (i) by applying deforestation probabilities: a forest at low risk of deforestation would provide less additionally if enrolled, so it should have a lower likelihood of being selected. They address (ii) through flexible payments that are aligned to landowner participation costs. Regarding (iii), they reduce the likelihood of the benefit exceeding the cost by selecting first the sites with the largest service-cost ratio. They conclude that targeting to reduce inefficiency (ii) yields the most significant increase in environmental service delivery. Nevertheless, estimating participation cost might not be an easy task since nonmonetary attitudes of the landowners, e.g. risk behavior, mistrust, or conservation preferences could influence the level of the landowner's real willingness to accept. They suggest inverse auctions as an alternative that could take such subjective attitudes into account. Technically, it appears that an auction system could easily be integrated into most PES programs in place. If landowners have to apply formally for program participation, their bid could be part of the application process. They also argue that and auction systems might also be a powerful way of making payment differentiation politically acceptable because service sellers suggest the price themselves. However, it could increase the service buyer's transaction costs, at least in the short run, as it would require changes in administrative processes.

Unfortunately, the existence of subsidies that promote excessive use of ecosystem services has had a negative impact on the uptake of AEPs. The high crop and livestock-related payments received by farmers under the EU's Common Agricultural Policy (CAP) contributed to the disincentives to participate, especially in higher tiers (Baylis et al. 2008). Furthermore, they also increase land values, adding to landowners' resistance to subsidy reductions.

Similar problems are created by subsidies to forestry or fishing. Although removal of production subsidies would produce net benefits, it would not occur without costs. The farmers and fishers benefiting directly from the subsidies would suffer the most immediate losses, but there would also be indirect effects on ecosystems both locally and globally. In 
some cases it may be possible to transfer production subsides to other activities that promote ecosystem stewardship, such as payment for the provision or enhancement of regulatory or supporting services. Compensatory mechanisms may be needed for the poor who are adversely affected by the immediate removal of subsidies. On the other hand, reduced subsidies within the OECD may lessen pressures on some ecosystems in those countries, but they could lead to more rapid conversion and intensification of land for agriculture in developing countries and would thus need to be accompanied by policies to minimize the adverse impacts on ecosystems there.

Bundling of services could increase the benefits to conservation and the political support for a payment scheme by increasing the beneficiaries of the program. It also eliminates the potential for the provision of one ecosystem service to crowd out another and may provide a more administratively efficient process for integrating different ecosystem services that are managed by different regulatory agencies (Deal et al. 2012). Moreover, if the services bundled have benefits across spatial scales, this is also a way to expand the potential market and increase payments to a particular area, yet it might increase transaction costs. However, bundling of services under a single credit type may also require buyers to purchase services that buyers do not want (Chan et al. 2007, Kroeger and Casey 2007, and Townsend et al. 2011) and it is important to be able to "unbundle" services from a broader suite of services to meet regulatory requirements for a specific service. Ideally, an integrative accounting system would "bundle" ecosystem services at a landscape scale and accommodate current jurisdictional limitations by separating out regulated credits and "stacking" them alongside other parts of the bundled services (Deal et al. 2012). For instance, Costa Rica's National Forestry Environmental Service's Program bundles the provisioning of carbon sequestration, watershed protection, biodiversity conservation, and scenic beauty services, and markets them to different buyers (Kemkes et al. 2010).

\section{Conclusions}

Biodiversity and ecosystem services are in serious jeopardy and the best hope to protect them is to create and align diverse incentives for conservation wherever possible and to integrate these into the larger policy-make arena. It is a major challenge to reverse the degradation of ecosystems while meeting increasing demands for their services. The evidence gathered over the last decades indicates that this challenge can be met if a series of major interventions are 
promptly developed. In fact, growth in the use of ecosystem services over the past five decades was generally much less than the growth in GDP (Millennium Assessment 2005). This change reflects structural changes in economies, but it also results from new technologies and new management practices and policies that have increased the efficiency with which ecosystem services are used and provided substitutes for some services. Even with this progress, though, the absolute level of consumption of ecosystem services continues to grow, which indicates that much more is needed to keep pace with growing pressures and demands.

Historically, conservation has largely relied on considerations of intrinsic value. This has been manifestly insufficient as a response to the increasing threats to biodiversity, particularly in the world's poorest regions, where considerations of intrinsic and spiritual values are often trumped by the needs for survival or used to exclude significant segments of the population from the benefits from their ecosystem resources. The reality, of course, is that our planet is a mosaic of systems providing people with different bundles of ecosystem services and disservices. We cannot manage these systems effectively if we do not actively seek to measure the flows of these services, examine who is benefiting from them, and consider a range of policies, incentives, technologies and regulations that could encourage better management and sharing of the benefits.

Global commons are increasingly a part of the policy debate as there is increasing recognition and willingness to act to reduce and reverse the effects of the long run de facto open access of the atmosphere, oceans, and overall stock of biodiversity. These global commons are threatened with degradation as a result of collective human activity but are much trickier to deal with than local natural resource commons. Not only are global commons degraded on a large scale by many diverse actors, but often the outcomes are spatially dispersed from the causes. In the case of climate change, those countries most negatively affected by climate change are often those low-income countries that have least caused the harm.

Local conservation depends on the existence of mechanisms to translate global willingness to pay for conservation into local incentives. In the absence of such incentives biodiversity conservation is unlikely to have high priority in the poorest countries. There has been a "relative" success in supporting local conservation throughout the creation of markets and the emergence of ecosystem services pricing. This is largely due to the fact that ownership of these services can be easily established through property rights. However, it must be recognized that many of the prices for these services are still far from perfect and that 
establishing prices for regulating, cultural and supporting ecosystem services raises a serious challenge since many of these services are public goods by definition. Moreover, the interlinkages between ecosystem services make the assignment of property rights slightly more complex. The use of many provisioning services has a direct impact on the flow of regulating, supporting and cultural services. In most instances, these impacts are negative. Therefore, extraction of timber from forest at rates above a certain threshold will cause the decline in water regulation, flood regulation and erosion control.

Even confining our interest to preservation of ecosystem services however is complex as there are likely to be many different goal conflicts. One might be between production of classical provisioning services and regulating, cultural or supportive services to use the terminology of the MA. Put simply, we might find that narrowly managed monocultures give us the most yields in terms of tons of food or fiber but relatively less in terms of aesthetics, wildlife, resilience and or such services as pollination. When we have a multitude of goals we typically find that we need to employ also a number of policy instruments and we have in this paper explored some way in which such instruments might be combined and(or) diversified in time and space.

Finally, the current focus on ecosystem services may sometimes be bundled with conservation of biodiversity for ethical reasons. In particular, measures can be developed that benefit both regulating and supporting ecosystem services on the one hand and nature conservation on the other. However, this will not always be the case and the focus on ecosystem services should not overshadow the need for traditional nature conservation. Similarly we cannot merely focus on preservation of species or conservation of protected areas; we need also to think of sensible, balanced, management of the big majority of areas that are in fact exploited commercially.

\section{References}

André F.J. and S. Smulders. 2004. Energy Use, Endogenous Technical Change and Economic Growth, Universidad Pablo de Olavide, Department of Economics and Business Administration, manuscript.

Ahrends A., N. D. Burgess, S. A. H. Milledge, M. T. Bulling, B. Fisher, J. C. R. Smarti, G. P. Clarke, B. E. Mhorok, and S. L. Lewis. 2010. Predictable waves of sequential forest 
degradation and biodiversity loss spreading from an African city. Proceedings of the National Academy of Sciences of the United States of America 107:14556-14561.

Albers, H. J. 2010. Spatial extraction and enforcement in developing country protected areas, Resource and Energy Economics 32:165-179.

Altieri, M. A. 1999. The ecological role of biodiversity in agroecosystem, Agriculture, Ecosystems and Environment 74: 19-31

Andam, K.S., P. J. Ferraro, A. Pfaff, G. A. Sanchez-Azofeifa, and J. A. Robalino. 2008. Measuring the effectiveness of protected area networks in reducing deforestation PNAS 105: 16089-16094.

Ando, A., J. Camm, S. Ploasky, and A. Solow. 1998. Species distributions, land values, and efficient conservation. Science 279:2126-2128.

Andersson, G., M. Rundlöf, and H.G. Smith. 2012. Organic farming improves pollination success in strawberries. PLoS One 7(2):e31599.

Arrow, K. J. and A. C. Fisher. 1974. Environmental Preservation Uncertainty, and Irreversibility, Quarterly Journal of Economics 88: 312-319.

Babcock, B. A., P.G. Lakshiminarayan, J.J. Wu, and D. Zilberman. 1997. Targeting tools for the purchase of environmental amenities. Land Economics 73: 325-329.

Balvanera, P., G.C. Daily, P.R. Ehrlich, T.H. Ricketts, S.A. Bailey, S. Kark, C. Kremen, and H. Pereira. 2001. Conserving biodiversity and ecosystem services. Science 291:2047-2047.

Barbier, E.B. 1997. Introduction to the environmental Kuznets curve special issue. Environment and Development Economics 2:369 -382

Baylis, K., S. Peplow, G. Rausser, L. Simon. 2008. Agri-environmental policies in the EU and United States: A comparison. Ecological Economics 65: 753-764.

Bayon, R. 2006. Biodiversity Offsets - From Laws to Theory”, presentation at the seminar Les mécanismes de compensation une opportunité pour les secteurs économiques et financiers et les gestionnaires de la diversité biologique, French Ministry of Ecology and Sustainable Development, Paris, 6 July 2006.

Bengtsson, J. 1998. Which species? What kind of diversity? Which ecosystem function? Some problems in studies of relations between diversity and ecosystem function. Applied Soil Ecology 10:191-199.

Bennear, L. and R. Stavins. 2007. Second-best theory and the use of multiple policy instruments. Environmental and Resource Economics 37: 111-129.

Bennett, E.M., G.D. Petterson, and L.J. Gordon. 2009. Understanding relationships among multiple ecosystem services. Ecological Letters 12: 1394-1404. 
Biesmeijer, J. C., S. P. M. Roberts, M. Reemer, R. Ohlemuller, M. Edwards, T. Peeters, A. P. Schaffers, S. G. Potts, R. Kleukers, C. D. Thomas, J. Settele, and W. E. Kunin. 2006. Parallel declines in pollinators and insect-pollinated plants in Britain and the Netherlands. Science 313:351-354.

Blignaut, J. and J. Aronson. 2008. Getting serious about maintaining biodiversity. Conservation Letters 1:12-17.

Bockstael, N.E. 1996. "Modeling economics and ecology: The importance of a spatial perspective, American Journal of Agricultural Economics 78:1168-1180.

Bulte, E. and G.C. van Kooten. 2000. Economic science, endangered species, and biodiversity loss. Conservation Biology 14:113-119.

Burgess, N. and Rodgers, A. 2004. Protected Area Categories: Why They Matter for the Eastern Arc and Coastal Forests in Tanzania - Briefing Note, Project Report No.05, Conservation and Management of the Eastern Arc Mountain Forests Project (CMEAMF), September.

http://easternarc.or.tz/downloads/easternarc/Protected\%20Area\%20Categories\%20v2_Sept04. doc, accessed 1 June 2009; verified 12 June 2009.

Busby, G. M., H. J. Albers, and C. A. Montgomery. Forthcoming, 2012. Wildfire Risk Management: Spatial Interdependence and Strategic Interaction. Land Economics.

Chan, K. M. A., R. M. Pringle, J. Ranganathan, C. L. Boggs, Y. L. Chan, P. R. Ehrlich, P. K. Haff, N. E. Heller, K. Al-khafaji, and D. P. Macmynowski. 2007. When Agendas Collide: Human Welfare and Biological Conservation. Conservation Biology 21: 59-68.

Chapin, F.S., E. S. Zavaleta, V. T. Eviner, R. L. Naylor, P. M. Vitousek, H. L. Reynolds, D. U. Hooper, S. Lavorel, O.E. Sala, S. E. Hobbie, M. C. Mack, and S. Díaz. 2000. Consequences of changing biodiversity. Nature 405:234-242.

Chisholm, R. A. 2010. Trade-offs between ecosystem services: Water and carbon in a biodiversity hotspot. Ecological Economics 69: 1973-1987.

Chomitz, K.M. and D.A. Gray. 1996. Roads, Land Use, and Deforestation: A Spatial Model Applied to Belize. The World Bank Economic Review 10: 487-512.

Clark, C. W. 1973. Profit maximization and the extinction of animal species. Journal of Political Economy 81: 950-961.

Coria, J. and T. Sterner. 2011. Natural Resource Management: Challenges and Policy Options. Annual Review of Resource Economics 3: 203-230.

Coria, J. and E. Calfucura. 2012. Ecotourism and the development of indigenous communities: The good, the bad, and the ugly, Ecological Economics 73: 47-55.

Crepin, S. 2007. Using Fast and Slow Processes to Manage Resources with Thresholds. Environmental and Resource Economics 36:191-213. 
Crowder, D.W., T.D. Northfield, M.R. Strand, and W.E. Snyder. 2010. Organic agriculture promotes evenness and natural pest control. Nature 466:109-112.

Deal, R.L., B. Cochran and G. LaRocco. 2012. Bundling of ecosystem services to increase forestland value and enhance sustainable forest management. Forest Policy and Economics, in press.

Díaz, S. D. Tilman, J. Fargione, F.S. Chapin, R. Dirzo, T. Kitzberger, B. Gemmill, M. Zobel, M. Vilá, C. Mitchell, A. Wilby, G. C. Daily, M. Galetti, W.F. Laurance, J. Pretty, R. L. Naylor, A. Power, and D Harvell. 2005. Biodiversity regulation of ecosystem services. In Ecosystems and Human Well-being. Island Press.

Dobbs, T. L., and J. Pretty. 2008. Case study of agri-environmental payments: The United Kingdom. Ecological Economics 65: 765-775.

Dudley, N. 2008. Guidelines for applying protected area management categories. International Union for Conservation of Nature, Gland, Switzerland.

Epstein, L. S. 1980. Decision-making and the Temporal Resolution of Uncertainty, International Economic Review 21: 269-284.

Elmqvist, T., C. Folke, M. Nyström, G. Peterson, J. Bengtsson, B. Walker, and J. Norberg. 2003. Response diversity, ecosystem change, and resilience. Frontiers in Ecology and the Environment 1:488-494.

Farley, J. and R. Constanza. 2010. Payments for ecosystem services: from local to global. Ecological Economics 69: 2060-2068.

Farzin, Y. H. 1984. The effect of the discount rate on depletion of exhaustible resources. Journal of Political Economy 92: 841-851.

Farzin, Y.H. 1992. The time path of scarcity rent in the theory of exhaustible resources. Economic Journal 102, 841-851.

Ferraro, P. J. 2002. The Local Costs of Establishing Protected Areas in Low-Income Nations: Ranomafana National Park, Madagascar. Ecological Economics 43:261-275.

Ferraro, P.J. 2008. Asymmetric information and contract design for payments for environmental services. Ecological Economics 65: 810-821.

Fisher, B., R. Kerry Turner, and P. Morling. 2009. Defining and classifying ecosystem services for decision making. Ecological Economics 68:643-653.

Fischer, J. et al. 2011. Conservation: Limits of land-sparing. Science 334:593-593.

Foley, J.A. 2005. Global consequences of land-use. Science 309:570-574.

Freixas, X. and J.J. Laffont. 1984. On the Irreversibility Effect, in M. Boyer and R. Kihlstrom, eds., Bayesian Models in Economic Theory. Elsevier, Dordrecht. 
Gamfeldt, L., H.Hillebrand, P.R. Jonsson. 2008. Multiple functions increase the importance of biodiversity for overall ecosystem functioning. Ecology 89:1223-1231.

Gaston, K.J. and R.A. Fuller. 2008. Commonness, population depletion and conservation biology. Trends in Ecology and Evolution 23:14-19

Gaston, K.J. 2010. Valuing common species. Science 327:154-155.

Gault, A., Y. Meinard, and F. Courchamp. 2008. Consumers' taste for rarity drives sturgeons to extinction. Conservation Letters 1: 199-207.

Gilbert-Norton, L., R. Wilson, J.R. Stevens, and K.H. Beard. 2010. A meta-analytic review of corridor effectiveness. Cons. Biol. 24:660-668.

Giller, K.E., M.H. Beare, P. Lavelle, A.-M.N. Izac, and M.J. Swift. 1997. Agricultural intensification, soil biodiversity and agroecosystem function. Appl. Soil. Ecol. 6:3-16.

Gómez-Baggethun, E., R. de Groot, P. L. Lomas, and C. Montes. 2010. The history of ecosystem services in economic theory and practice: From early notions to markets and payment schemes. Ecological Economics 69: 1209-1218.

Green, R.E., S.J. Cornell, J.P.W. Scharlemann, and A. Balmford. 2005. Farming and the fate of wild nature. Science $307,550-555$.

Hannesson, R. 1987. The Effect of the Discount Rate on the Optimal Exploitation of Renewable Resources. Marine Resource Economics 3: 319-329.

Hartshorn, G., P.J. Ferraro, and B. Spergel. 2005. Evaluation of the WorldBank - GEF Ecomarkets Project in Costa Rica. Worldbank, Washington DC.

Hanski, I. 1999. Metapopulation Ecology, Oxford University Press.

Henry, C. 1974. Investment Decisions Under Uncertainty: The "Irreversibility Effect', American Economic Review 64: 1006-1012.

Hodgson, J.A., W.E. Kunin, C.D. Thomas, T. Benton, and D. Gabriel. 2010. Comparing organic farming and land sparing: optimizing yield and butterfly populations at a landscape scale. Ecology Letters 13:1358-1367.

Hodgson, J.A., A. Moilainen, B.A. Wintle, and C.D. Thomas. 2011. Habitat área, quality and connectivity: striking the balance for efficient conservation. Journal of Applied Ecology 48:148-152.

Hooper, D.U. et al. 2005. Effects of biodiversity on ecosystem functioning: a consensus of current knowledge. Ecological Monographs 75:3-35.

Hotelling, H. 1931. The economics of exhaustible resources. The Journal of Political Economy 39: 137-175. 
Isbell, F., V. Calcagno, A. Hector, J. Connolly, W. Stanley Harpole, P. B. Reich, M. SchererLorenzen, B. Schmid, D. Tilman, J. van Ruijven, A. Weigelt, B. J. Wilsey, E.S. Zavaleta, and M. Loreau. 2011. High plant species diversity is needed to maintain ecosystem services. Nature 477:199-202.

Joppa, L.N. and A. Pfaff. 2009. High \& Far: how the world's protected areas have avoided threat". Duke University Nicholas School of the Environment Working Paper.

Kemkes, R.J., J. Farley and C. J. Koliba. 2010. Determining when payments are an effective policy approach to ecosystem service provision. Ecological Economics 69: 2075-2084.

Key, N., E. Sadoulet, and A. de Janvry. 2000. Transactions Costs and Agricultural Supply Response. American Journal of Agricultural Economics 82: 245-259.

Kleijn, D. and W. J. Sutherland. 2003. How effective are European agri-environment schemes in conserving and promoting biodiversity? Journal of Applied Ecology. 40:947-969.

Kleijn, D., F. Berendse, R. Smit, and N. Gilissen. 2001. Agri-environment schemes do not effectively protect biodiversity in Dutch agricultural landscapes. Nature 413:723-725.

Kleijn, D., R. A Baquero, Y. Clough, M. Diaz, J. De Esteban, F. Fernandez, D. Gabriel, F. Herzog, A Holzschuh, R. Jöhl, E. Knop, A. Kruess, E J. P. Marshall, I. Steffan-Dewenter, T. Tscharntke, J. Verhulst, T. M. West, and J. L. Yela. 2006. Mixed biodiversity benefits of agrienvironment schemes in five European countries. Ecology Letters 9:243-254.

Kleijn, D., M. Rundlof, J. Scheper, H. G. Smith, and T. Tscharntke. 2011. Does conservation on farmland contribute to halting the biodiversity decline? Trends in Ecology \& Evolution 26:474-481.

Kohler, F., J. Verhulst, R. Van Klink, and D. Kleijn. 2008. At what spatial scale do highquality habitats enhance the diversity of forbs and pollinators in intensively farmed landscapes? Journal of Applied Ecology 45:753-762.

Kosoy, N. and E. Corbera. 2010. Payment for ecosystem services as commodity fetishism. Ecological Economics 69: 1228-1236.

Kroeger, T. and F. Casey. 2007. An assessment of market-based approaches to providing ecosystem services on agricultural lands. Ecological Economics 64: 321-332.

Landell-Mills, N. and I.T. Porras. 2002. Silver bullet or fool's gold? A global review of markets for forest environmental services and their impact on the poor, Instruments for sustainable private sector forestry series, International Institute for Environment and Development, London.

Lant, C.L., J. B. Ruhl, and S. E. Kraft. 2008. The tragedy of ecosystem services. BioScience 58:969-974.

Leadley, P., H.M. Pereira, R. Alkemade, J.F. Fernandez-Manjarrés, V. Proença, J.P.W. Scharlemann, M.J. Walpole, et al. 2010. Biodiversity Scenarios: Projections of the $21^{\text {st }}$ 
Century Change in Biodiversity and Associated Ecosystem Services. In: Report of the Convention on Biological Diversity, Montreal, Canada.

Leal, I. R., J.M.C Da Silva, M. Tabarelli, and T.E. Lacher. 2005. Changing the Course of Biodiversity Conservation in the Caatinga of Northeastern Brazil. Conservation Biology 19: 701-706.

Lewis, J. 2002. Scarcity and Abundance. Contrasting Conceptions of the Forest in Northern Congo-Brazzaville, and Issues for Conservation, Ninth International Conference on Hunting and Gathering Societies, Edinburgh Conference Centre, Heriot-Watt University, September 913.

Lindenmayer, D. B. and H. A. Nix. 1993. Ecological Principles for the Design of Wildlife Corridors, Conservation Biology 7: 627-630.

Lokina, R.B., E.J.Z. Robinson, and H. Eggert. 2008. Determinant of the effectiveness of participatory forest management in Tanzania, presented at the European Association of Environmental and Resource Economists 16th Annual Conference, Gothenburg, Sweden, 2528 June.

Lyons, K.G, C.A. Bringham, B.H. Traut, M.W. Schwartz. 2005. Rare species and ecosystem functioning. Conservation Biology 19:1019-1024.

Mace, G.M., K. Norris, A.H. Fitter. 2012. Biodiversity and ecosystem services: a multilayered relationship. Trends in Ecology and Evolution 27:19-26.

MacDonald D.H., W.L. Adamowicz, and M.K. Luckert. 2001. Fuelwood collection in NorthEastern Zimbabwe: valuation and caloric expenditures. Journal of Forestry Economics 7:2952

McCauley, D. 2006. Selling out on nature. Nature 443: 27-28.

Millennium Ecosystem Assessment (2005) Ecosystems and human well-being: current state and trends: findings of the condition and trends working group. Island Press, Washington, DC.

Moilanen, A., K. A. Wilson, and H. Possingham. 2009. Spatial Conservation Prioritization. Oxford University Press.

Naughton-Treves, L., M. Buck, and K. Brandon. 2005. The Role of Protected Areas in Conserving Biodiversity and Sustaining Local Livelihoods. Annual Review of Environment and Resources. 30:219-252.

Nelson, G.C. and D. Hellerstein. 1997. Do Roads Cause Deforestation? Using Satellite Images in Econometric Analysis of Land Use. American Journal of Agricultural Economics 79: 80-88.

Omamo, S. Were. 1998. "Transport Costs and Smallholder Cropping Choices: An Application to Siaya District, Kenya.” American Journal of Agricultural Economics 80: 116-23. 
Ortiz, E., Sage Mora, L.F., Borge Carvajal, C., 2003. Impacto del Programa de Pago por Servicios Ambientales en Costa Rica como Medio de Reducción de la Pobreza en los Medios Rurales. RUTA, San José, Costa Rica.

Ostrom, E. 1990. Governing the Commons: The Evolution of Institutions for Collective Action. Cambridge University Press.

Öckinger, E. and H. G. Smith. 2007. Semi-natural grasslands as population sources for pollinating insects in agricultural landscapes. Journal of Applied Ecology 44:50-59, 2007.

Pagiola, S., J. Bishop and N. Landell-Mills. 2002. Making Market-based Mechanisms work for Forests and People, in Pagiola, S., J. Bishop and N. Landell-Mills (editors): Selling Forest Environmental Services - Market based Mechanisms for Conservation and Development, Earthscan Publication, London and Sterling.

Pagiola, S., 2008. Payments for environmental services in Costa Rica. Ecological Economics 65: 712-724.

Perrings, C. 2007. Pests, pathogens and poverty: biological invasions and agricultural dependence. In: KontoleonA, Pascual U, Swanson T (eds) Biodiversity economics: principles, methods, and applications. Cambridge University Press, Cambridge, pp. 133-165

Perrings, C. and G. Halkos, 2012. Who Cares about Biodiversity? Optimal Conservation and Transboundary Biodiversity Externalities. Environmental and Resource Economics, forthcoming.

Pfaff, A.S.P. 1999. What drives deforestation in the Brazilian Amazon? Evidence from satellite and socioeconomic data. Journal of Environmental Economics and Management 37: 26-43.

Pfaff, A., Robalino, J., Sanchez-Azofeifa, G.A., Andam, K. and Ferraro, P., 2009 "Park Location Affects Forest Protection: Land Characteristics Cause Differences in Park Impacts across Costa Rica," The B.E. Journal of Economic Analysis \& Policy: 9 (2) (Contributions), Article 5.

Phalan, B., M. Onial, A. Balmford and R.E. Green. 2012. Reconciling food production and biodiversity conservation: land sharing and land sparing compared. Science 333:1289-1291.

Pindyck, R. 1978. The Optimal Exploration and Production of Nonrenewable Resources. Journal of Political Economy 86: 841-861.

Raudsepp-Hearne, C., G. D. Peterson, and E. M. Bennett. 2010. Ecosystem service bundles for analyzing tradeoffs in diverse landscapes. PNAS 16: 5242-5247.

Rey Benayas, J.M., A. C. Newton, A. Diaz, and J. M. Bullock. 2009. Enhancement of Biodiversity and Ecosystem Services by Ecological Restoration: A Meta-Analysis. Science 325:1121-1124. 
Ridder, B. 2008. Questioning the ecosystem services argument for biodiversity conservation. Biodiversity and Conservation 17: 781-790.

Robinson, E. J. Z., J.C. Williams, and H. J. Albers. 2002. The Influence of Markets and Policy on Spatial Patterns of Non-Timber Forest Product Extraction. Land Economics 78: 260-271.

Robinson, E. J. Z., H.J. Albers, and J.C. Williams. 2008. Spatial and Temporal Modelling of Community Non-Timber Forest Extraction. Journal of Environmental Economics and Management 56: 234-245.

Robinson, E. J. Z., H.J. Albers, and J. Williams. 2011. Sizing reserves within a landscape: The roles of villagers' reactions and the ecological-socioeconomic setting, Land Economics 87: 233-249.

Rockström, J., W. Steffen, K. Noone, Å. Persson, F. S. Chapin III, E. F. Lambin, T. M. Lenton, M. Scheffer, C. Folke, H. J. Schellnhuber, B. Nykvist, C. A. de Wit, T. Hughes, S. van der Leeuw, H. Rodhe, S. Sörlin, P. K. Snyder, R. Costanza, U. Svedin, M. Falkenmark, L. Karlberg, R. W. Corell, V. J. Fabry, J. Hansen, B. Walker, D. Liverman, K. Richardson, P. Crutzen, and J. A. Foley. 2009. A safe operating space for humanity. Nature 461:472-475.

Rodrigues A.S.L., J.P. Pilgrim, J.L. Lamoreux, M. Hoffmann, and T.M. Brooks. 2006. The value of the Red List for conservation. Trends in Ecological Evolution 21:71-76

Rouget, M., R. M. Cowling, A. T. Lombard, A. T. Knight, and G. I. Kerley. 2006. Designing Large-Scale Conservation Corridors for Pattern and Process. Conservation Biology 20: 549561.

Rundlöf, M. and H. G. Smith. 2006. The effect of organic farming on butterfly diversity depends on landscape context. Journal of Applied Ecology 43:1121-1127.

Scheffer, M., S. Carpenter, J.A. Foley, C. Folke, and B. Walker. 2001. Catastrophic shifts in ecosystems. Nature 413:591-596.

Scheffer, M. 2009. Critical Transitions in Nature and Society. Princeton University Press.

Scherr, S. A. Khare, and A. White. 2004. For services rendered. Current status and future potential of markets for ecosystem services of tropical forests: an overview", Technical Series 21, ITTO.

Schleisinger, W.H. 2009. Planetary boundaries: Threshold risk prolonged degradation. Nature Reports Climate Change 3:112-113,

Schröder, A., L. Persson, and A.M. De Roos. 2005. Direct experimental evidence for alternative stable states: a review. Oikos 110:3-19.

Sills, E. O., and K.L Abt (Eds.). 2003. Forests in a market economy -- (Forestry sciences; v. 72). Dordrecht; Boston: Kluwer Academic Publishers 
Sills, E., R. Arriagada, S. Pattanayak, F. Ferraro, L. Carrasco, E. Ortiz, and S. Cordero. 2006. Impact of the PSA program on land use. Paper presented at the Workshop on Costa Rica's Experience with Payments for Environmental Services. San José, 25-26 September 2006.

Sims, K. 2011. Do Protected Areas Reduce Forest Fragmentation? A Microlandscapes Approach. Amherst College Submitted working paper, (December). Available on line https://www.amherst.edu/media/view/363257/original/Sims-Fragmentation_12_8_11.pdf (accessed 2 April 2012).

Smith, H.G., E. Öckinger, and M. Rundlöf. 2010. Biodiversity and the landscape ecology of agri-environment schemes. Aspects of Applied Biology 100:225-232,

Srivastava, D.S. and M. Vellend. 2005. Biodiversity-ecosystem function research: Is it relevant to conservation? Annual Review of Ecological Systems 36:267-294.

Tallis, H., P. Kareiva, M. Marvier, and A. Chang. 2008. An ecosystem services framework to support both practical conservation and economic development. PNAS 105: 9457-9464.

Thompson, R and B. M. Starzomski. 2007. What does biodiversity actually do? A review for managers and policy makers. Biodiversity and Conservation 16: 359-1378

Townsend, P.V., R.J. Harper, P.D. Brennan, C. Dean, S. Wu, K.R.J. Smettem, and S.E. Cook. 2011. Multiple environmental services as an opportunity for watershed restoration. Forest Policy and Economics.

Tscharntke, T, I. Steffan-Dewenter, A. Kruess, and C. Thies. 2002. Contribution of small habitat fragments to conservation of insect communities of grassland-cropland landscapes. Ecological Applications 12:354-363, 2002.

Tscharntke, T., A. M. Klein, A. Kruess, I. Steffan-Dewenter, and C. Thies. 2005. Landscape perspectives on agricultural intensification and biodiversity - ecosystem service management. Ecological Letters 8:857-874.

Venter, O., W. F. Laurance, T. Iwamura, K. A. Wilson, R. A. Fuller, and H. P. Possingham. 2009. Harnessing carbon payments to protect biodiversity. Science 326:1368-1368.

Vira, B. and W. M. Adams. 2009. Ecosystem services and conservation strategy: beware the silver bullet. Conservation Letters 2: 158-162.

Wells, M., K. Brandon, and L. Hannah. 1992. People and parks: linking protected area management with local communities, World Bank, World Wildlife Fund and US Agency for International Development, Washington, DC.

Wendland, K. J., M. Honzák, R. Portela, B. Vitale, S. Rubinoff, J. Randrianarisoa. 2010. Targeting and implementing payments for ecosystem services: Opportunities for bundling biodiversity conservation with carbon and water services in Madagascar. Ecological Economics 69: 2093-2107 
Worm, B, E. B. Barbier, N. Beaumont, J. Emmett Duffy, C. Folke, B. S. Halpern, J. B. C. Jackson, H. K. Lotze, F. Micheli, S. R. Palumbi, E. Sala, K. A. Selkoe, J. J. Stachowicz, R. Watson. 2006. Impacts of Biodiversity Loss on Ocean Ecosystem Services. Science 314: 787790 .

Woodroffe, R. and J. R. Ginsberg. 1998. Edge Effects and the Extinction of Populations inside Protected Areas. Science 280 (5372): 2126-2128.

Wu, J. and W.G. Boggess. 1999. The Optimal Allocation of Conservation Funds. Journal of Environmental Economics and Management 38: 302-321.

Wunder, S. 2005. Payments for environmental services: some nuts and bolts. Occasional Paper No. 42. Bogor, CIFOR.

Wünscher, T., S. Engel, and S. Wunder. 2008. Spatial targeting of payments for environmental services: A tool for boosting conservation benefits. Ecological Economics

Zang, W., H. Taylor, C. Ricketts, K. Kremen, K. Carney, and S. M. Swinton. 2007. Ecosystem services and dis-services to agriculture. Ecological Economics 64:253-260. 